\title{
Analysis of Stoppages in the Process of Roadway Drivage Caused by Exceeding the Maximum Allowable Level of Methane Concentration
}

\author{
Jarosław Brodny, Magdalena Tutak, \\ Silesian University of Technology, Poland \\ Dariusz Felka \\ Łukasiewicz Research Network, \\ Institute of Innovative Technologies EMAG, Poland \\ Dorota Palka \\ Silesian University of Technology, Poland
}

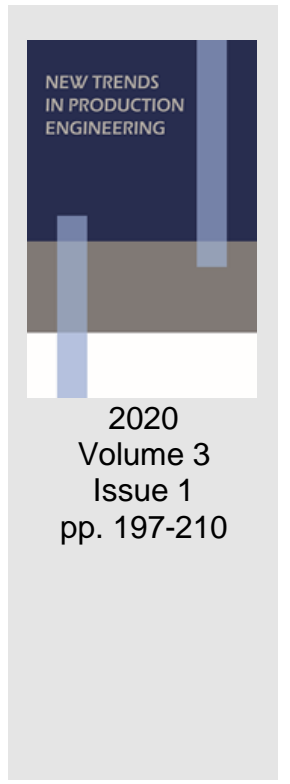

Date of submission to the Editor: 02/2020

Date of acceptance by the Editor: 03/2020

\section{INTRODUCTION}

The methane hazard belongs to one of the most dangerous natural threats present in Polish hard coal mines. The source of this threat lies in methane being emitted from coal. Methane is an odourless, flammable and explosive gas which is inherent in the process of coal exploitation. Due to its features, this gas not only represents a very serious threat to the health and life of mine workers, but also significantly disturbs the process of mining exploitation (Brodny \& Tutak, 2016a; Brodny \& Tutak, 2016b; Brodny \& Tutak 2016c; Brodny \& Tutak, 2018; Krause \& Dziurzyński, 2015; Tutak \& Brodny, 2017). During exploitation, methane is released into mine headings mainly from the coal being mined. As a result of the crevices and cracks in the rock mass formed during the exploitation process, this gas moves into the mined headings from the entire area affected by the consequences of exploitation. Consequently, this gas represents a threat not only during the drivage of roadways, but also during the exploitation itself in the mine face.

The methane permeating into these headings makes it necessary to take measurements of its concentration level and other ventilation parameters. These measurements are required in order to prevent the formation of dangerous concentration levels of this gas. This is because such levels may result in fires or methane explosions. Therefore, the task of ventilation service teams that use methane monitoring systems is to prevent such a situation. However, when it does happen, the exploitation process is stopped and ventilation activities intensified in order to reduce methane concentration. When its level is below the critical values again, the exploitation process is resumed. It is therefore clear that exceeded limit values of methane concentration in mine headings disturb the process of their exploitation. This is followed by an increase 
in the production costs, leading to reduced effectiveness of this process. These phenomena affect both longwall headings, where the fundamental process of mining exploitation occurs, and dog headings, which are auxiliary headings. This is particularly important in the case of dog headings, which are most commonly mined as the so-called "blind" headings with only one connection with the main pathways of air flow (Branny \& Filipek, 2008; Szlązak \& Borowski, 2006; Tutak, 2020). These are most frequently preparatory headings, which perform ventilation and transportation functions in the exploitation process.

Such headings, whose length may range from a few dozen to a few hundred metres, can only be ventilated using a duct line ventilation system. The air stream that must be supplied to the mine face needs to provide the working crew with adequate work comfort determined by the chemical composition, humidity, temperature and speed of the flowing air (Tutak, 2020). Practically, the purpose of ventilating such headings is to prevent the occurrence of excessive concentration levels of dangerous gases present during the drivage of roadways, and this mainly applies to methane (Brodny \& Tutak, 2016a; Brodny \& Tutak, 2016b; Brodny \& Tutak 2016c; Brodny \& Tutak, 2018; Krause \& Dziurzyński, 2015; Tutak \& Brodny, 2017).

In recent years, due to the exploitation of coal seams with increasing methanebearing capacity and located at increasing depths, the methane hazard is becoming higher and higher. This situation, especially in the case of longwall headings, is made worse also by the growing concentration of mining operations (Krause, 2019). All of the above-mentioned factors make the methane hazard in the current process of mining production an increasingly important factor affecting the safety and effectiveness of this process. Therefore, it is necessary to conduct research and analyses in order to improve this situation, i.e. to minimise the risk of explosions and methane combustion, as well as the risk of excessive methane concentration in mine headings.

In the literature published to date on the methane hazard, the subject of the papers dedicated to this issue revolves around the forecasting of methane release into mine headings (Krause, 2015) and the forecasting of methane concentration in those headings (Tutak \& Brodny, 2019), methane drainage from mine headings (Szlązak, 2013) and the methane prevention measures in use (Krause, 2005). Along with the recent development of cutting-edge IT tools, it is becoming increasingly common to apply CFD methods for analysing the distribution of methane concentration in mine headings (Brodny \& Tutak, 2019a; Kurnia et al., 2014; Tutak \& Brodny 2018) and state-of-the-art systems for diagnosing the status of gas hazards, including those related to methane.

From the perspective of the issue at hand, it is worthwhile to mention a few of the most significant papers in this regard. The paper (Wasilewski et al., 2014) presents an analysis of disturbances in air parameters (including methane concentration) in longwall areas formed as a results of short circuits on the brattices registered by the mine's gasometric system. The circulatory disturbances tend to be abrupt and affect the air speed, thus increasing the concentration of methane. On the other hand, the authors of the paper assessed 
the usefulness of the data collected by the sensors of the gasometric system for modelling the numerical flow of air in the mine's ventilation network. Based on their analysis, the authors demonstrated that the data registered by the sensors in underground systems of automatic gasometry may be useful for the purposes of modelling the numerical air flow in mining ventilation systems.

Those and a series of other papers attach growing importance to effective monitoring systems and the data they register. This is because such data serve as the basis for developing effective systems of diagnosing and forecasting hazards as well as making precise assessment of the actual impact of machines' downtimes caused by increased methane concentration on the production process.

The last issue is addressed in this paper. It encompasses an analysis of machines' downtimes in a dog heading caused by exceedances of the maximum allowable level of methane concentration in those headings. The research, whose results are presented in the paper, is based on the data registered by the automatic methanometry system installed in the heading under analysis. Undertaking this subject is extremely significant from the perspective of how effective the drivage of the roadway under analysis is. Moreover, no paper dedicated to the issue of methane hazard has so far included any analysis of the duration and causes of exceedances of the maximum allowable level of methane concentration in mine headings, including roadways. The automatic methanometry systems used in hard coal mines provide a large amount of information concerning the disturbances in air parameters in the form of exceedances of the maximum allowable levels of methane concentration in mine headings. This analysis is crucial from the perspective of exploitation safety and the effectiveness of mining a new roadway and the concept of sustainable development, which - in the context of mining activities assumes the maintenance of balance between production and the economic results achieved versus the safety requirements and the expenditures for safety improvement (Brodny \& Tutak, 2019). Therefore, the authors analysed the duration and causes of exceedances of the maximum allowable level of methane concentration in one of the roadways for a 4-week drivage period.

The total duration of exceedances of the maximum allowable level of methane concentration and the total duration of downtimes in cutting the roadway were determined for this period. The analysis also made it possible to identify the most common causes behind the exceedances of the maximum allowable level of methane concentration (according to Polish regulations).

\section{METHODOLOGY OF RESEARCH}

\section{Area of research}

The analysis of the duration and causes of exceedances of the maximum allowable level of methane concentration in a roadway was conducted for one of such roadways in one of the mines located within the Upper Silesian Coal Basin. The location of the region under analysis is presented in Figure 1. 


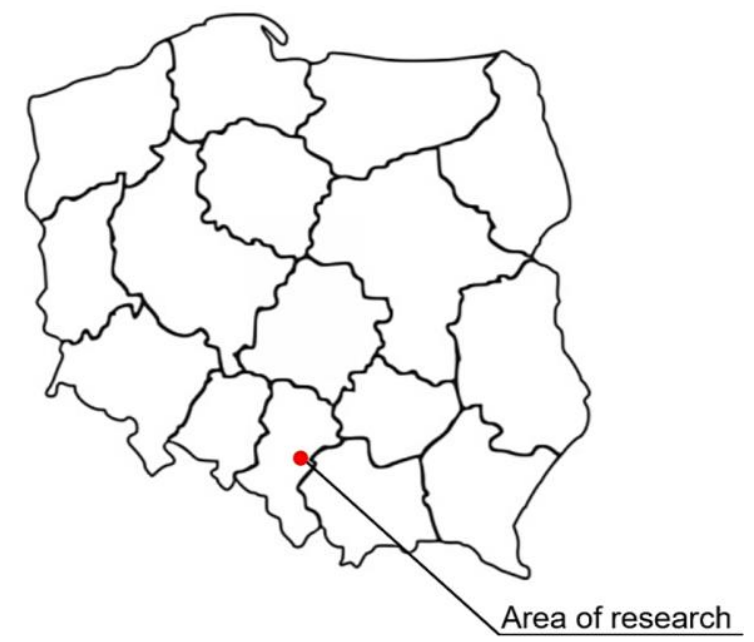

Fig. 1 Location of the region where the tests were conducted

The roadway encompassed by the research was mined in seam 501, located at the depth of 865 metres. The model of the heading under analysis, along with the indication of the installation sites of the automatic methane sensors, is presented in Figure 2.

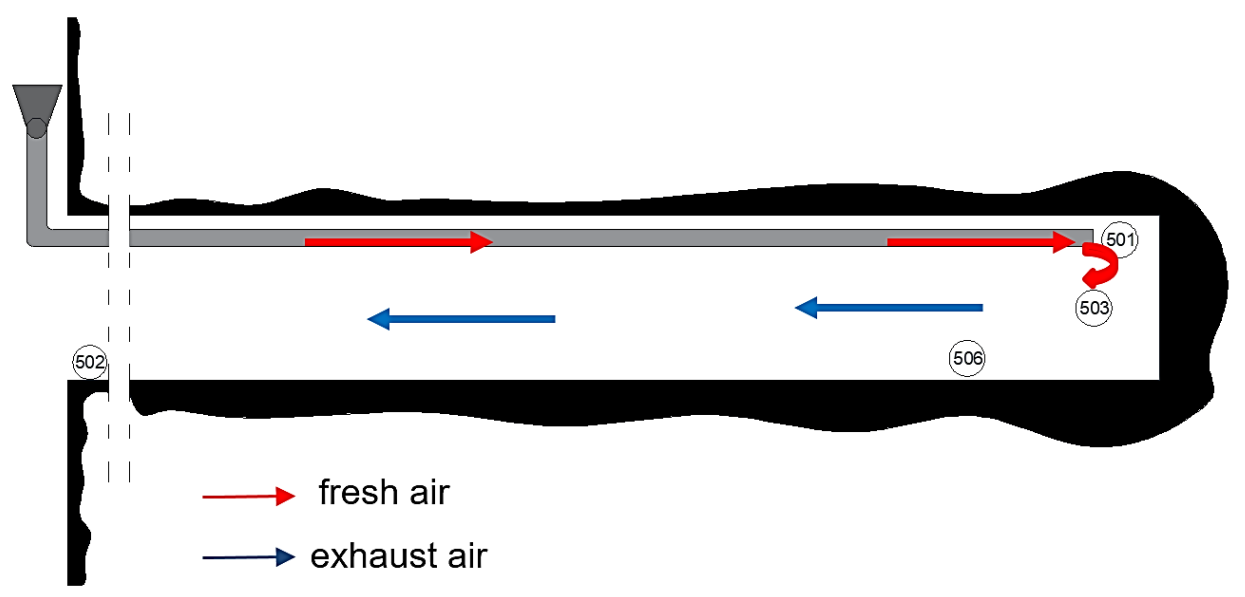

Fig. 2 Deployment of automatic methane sensors (M1-M501, M2-503, M3-506 and M4-502)

The analysis, with reference to determining the duration and causes of exceedances of the maximum allowable level of methane concentration, was based on the results registered by the automatic methane sensors marked in Figure 2.

\section{Regulations concerning the methane hazard in roadways}

With respect to detailed requirements related to the safety of mining operations in underground hard coal mines, Poland has implemented the provisions set forth in the Regulation of the Minister of Energy of 23 November 2016 on detailed requirements for the operation of underground mining plants (Ordinance of the Minister of Energy, 2016). 
The cutting of compact rocks with high and medium sparking tendency in roadways using road headers is allowed only when the concentration of methane in the air flow is not higher than:

- $0.5 \%$ - in the case of measurements taken with an automatic methane sensor placed under the roof of the roadway at a distance not higher than $2 \mathrm{~m}$ from the face and causing the road header to switch off;

- $1 \%$ - in the case of mining with a road header equipped with internal cutting knife spraying systems or other tools reducing the risk of methane ignition, whose ignition protection has been confirmed by relevant tests.

According to the regulations included in the publication (Ordinance of the Minister of Energy, 2016), concerning the methane hazard in roadways, where the level of methane concentration in the air is found to exceed $2 \%$, it is mandatory to immediately:

- switch off the mains;

- immobilise all the machines and devices;

- notify the nearest member of the mine's supervisory personnel;

- take additional measurements of methane concentration in order to determine the causes of the exceeded values, the degree of methane accumulation and the area of its outflow;

- undertake actions aimed at removing the accumulation of methane (in compliance with the rules specified by the manager of a mining plant).

If the level of methane concentration in the heading is found to exceed $3 \%$, it is also necessary to evacuate the staff working there.

In headings ventilated by means of air ducts, the methane sensors are placed under the roof of the heading. In the case of using suction ventilation, the distance of the sensor between the front of the mined face and the air inlet into the suction air duct may not be higher than $6 \mathrm{~m}$. In the case of using forced-air ventilation, the methane sensor should be placed at a distance not exceeding $10 \mathrm{~m}$ from the front of the mined face, in the area where the highest accumulation of methane occurs.

Additionally, in methane-bearing fields with methane explosion hazard category II, III or IV, the methane sensor is placed on the arm of the cutting head of a road header.

Additionally, in a roadway ventilated by means of a duct line ventilation system combined with a dust collection system, it is common to place initialisation methanometers disconnected from the power supply of the electric devices found in this roadway, after exceeding $1 \%$ of methane concentration in the air. The sensors of methanometers are placed:

- in the stream of air flowing out of the dust collection system;

- under the roof of a heading in the zone between the outlet of the air stream from the dust collection system and the outlet of air from the main forcing air duct.

The regulations presented provide the basis for practical application. This particularly concerns the immobilisation of machines in the heading, which 
is associated to obvious downtimes in their operation and reduction in the effectiveness of the entire process.

\section{Characteristics of an automatic methanometry system}

The system of automatic methanometry is part of the entire dispatching system of automatic gasometry, representing a set of control and measuring devices and transmission units. It allows for controlling the physical and chemical parameters of the mine air, as well as the status and operational parameters of ventilation devices and the operational parameters of technological machines and equipment (significant from the perspective of safety).

The system of automatic methanometry consists of intrinsically safe control and measuring devices supplied from the ground, which makes it possible for the system to fulfil its functions, irrespective of the status of the underground electricity grid (Dziurzyński et al., 2015).

An essential feature of the automatic methanometry with regard to the measurement and registration of methane concentration levels at the installation site of the sensor is the possibility to switch off the power supply in emergencies and critical situations, i.e. when the level of methane concentration has exceeded the limit value. It is possible to switch off the electricity and block its re-activation from different levels, e.g. directly through the outlets of methanometres and indirectly (locally) through an underground control panel, as well as centrally from a computer on the ground.

\section{RESULTS AND DISCUSSION}

As already pointed out, the analysis of duration and causes of the exceedances of the maximum allowable level of methane concentration conducted for the roadway encompassed a period of 4 weeks. The analysis was performed on the basis of data from automatic methanometry sensors, the deployment of which is presented in Figure 2, in compliance with the provisions applicable in Poland (Ordinance of the Minister of Energy, 2016).

The first stage of the analysis involved determining the duration of exceedances of the maximum allowable level of methane concentration on the particular days in the mined heading, registered by a given sensor of the automatic methanometry. As every single exceedance of the maximum allowable level of methane concentration leads to a stoppage of the technological process of heading excavation, the duration of downtimes caused by those exceedances were also determined. The results obtained for the particular sensors have been presented in Figures 3-6. 


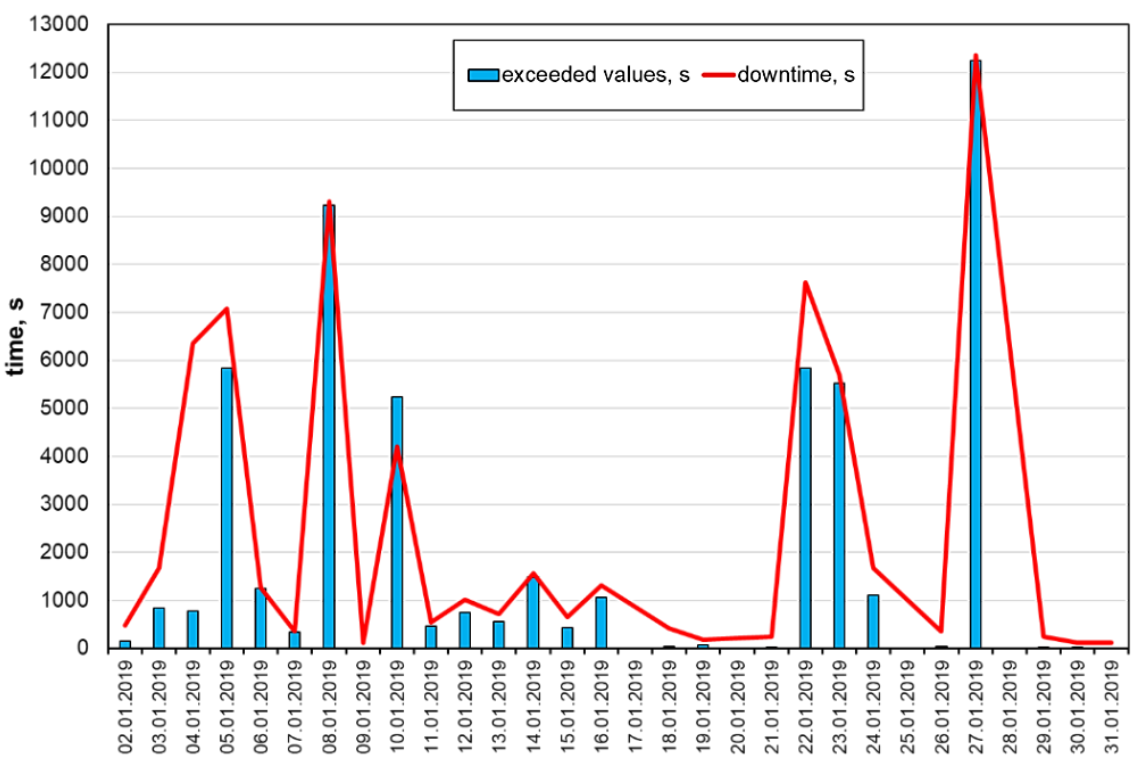

Fig. 3 The exceedance times of the maximum allowable level of methane concentration registered by the M-501 sensor and the downtimes caused by these

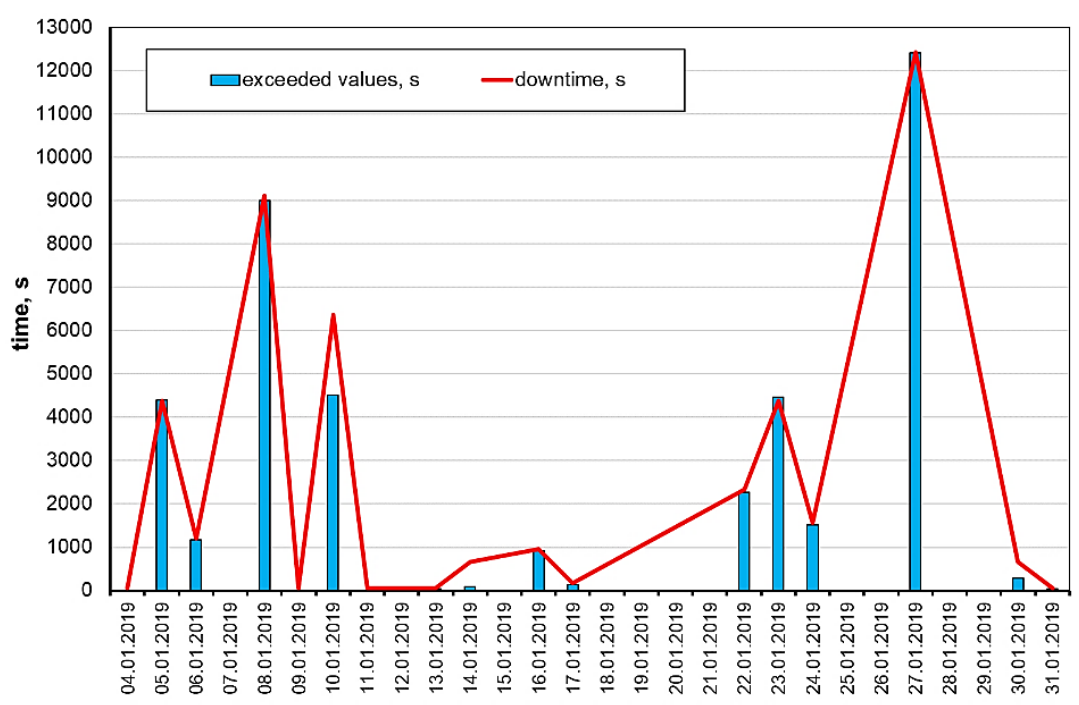

Fig. 4 The exceedance times of the maximum allowable level of methane concentration registered by the M-503 sensor and the downtimes caused by these

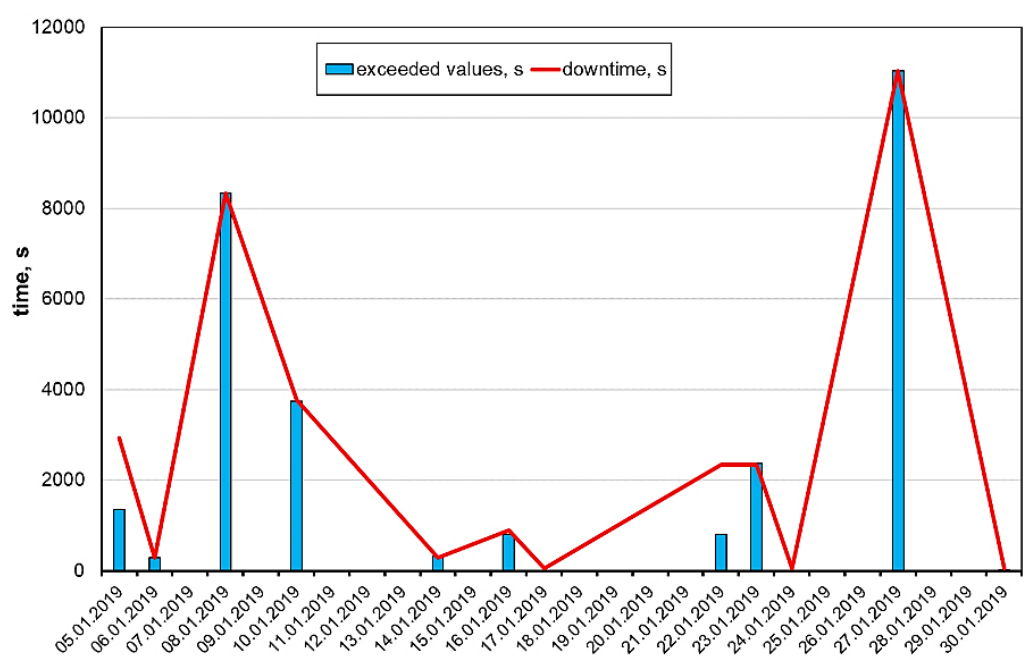

Fig. 5 The exceedance times of the maximum allowable level of methane concentration registered by the M-506 sensor and the downtimes caused by these 


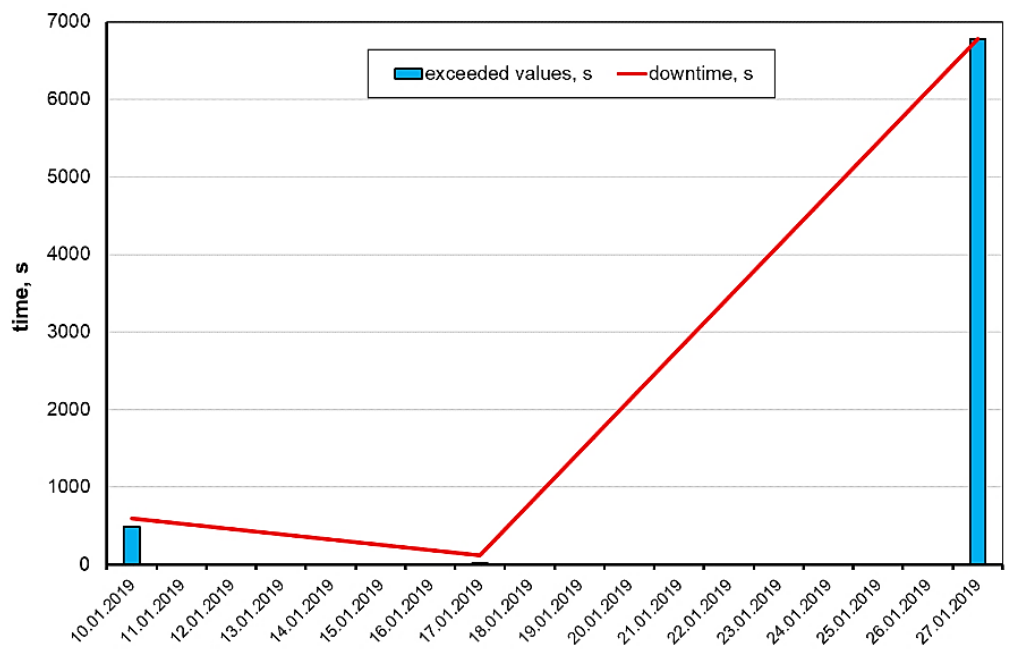

Fig. 6 The exceedance times of the maximum allowable level of methane concentration registered by the M-502 sensor and the downtimes caused by these

A summary list of downtimes corresponding to the exceedances of the maximum allowable levels of methane concentration for the particular sensors is shown in Figure 7.

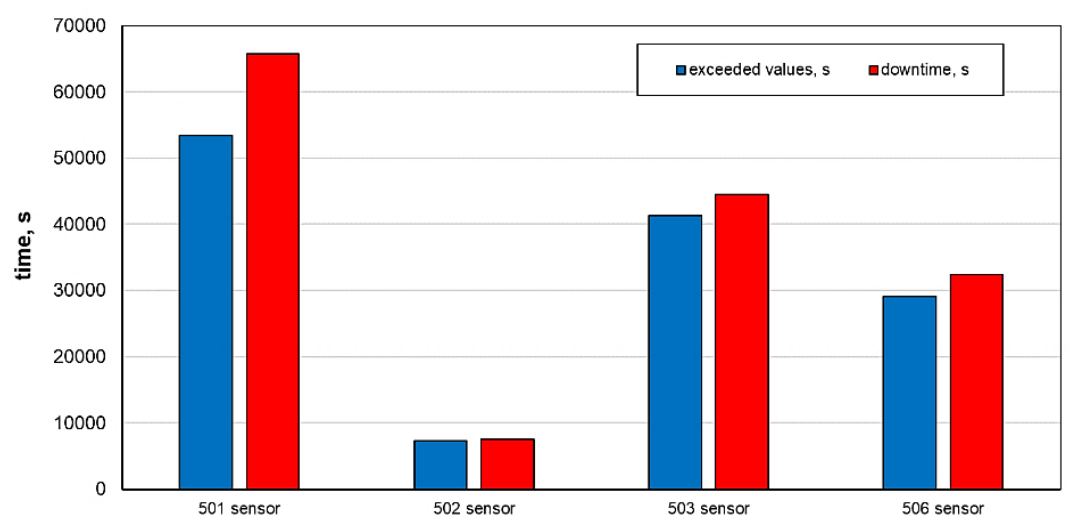

Fig. 7 Summary downtimes corresponding to the exceedances of the maximum allowable levels of methane concentration for the particular sensors

Analysing the results obtained, it may be concluded that the values of exceedance times of the maximum allowable level of methane concentration registered by the particular sensors and the durations of downtimes are highly diverse. The closer to the face of the mined heading the sensor was installed, the more exceedances of the maximum allowable level of methane concentration it registered, which resulted in longer downtimes.

Based on the calculations made, it is necessary to state that the greatest number of exceedances of the maximum allowable level of methane concentration and the durations of production downtime was registered by the M-501 sensor. The total duration of exceedances of the maximum allowable level of methane concentration amounted to 53,365 seconds (nearly 15 hours), and the total duration of downtimes $-65,700$ seconds (over 18 hours). It should be noted that, with respect to stopping the technological process, this is only the duration 
of downtimes caused by the exceedances of the maximum allowable levels of methane concentration.

The analyses conducted also made it possible to determine the sensor which, during the period under analysis, registered the shortest duration of exceedances of the maximum allowable level of methane concentration and downtimes. This sensor was installed at the outlet from the mined heading (sensor M-502). For an analysis period of 4 weeks, the duration of exceedances of the maximum allowable level of methane concentration and downtimes in the case of this sensor amounted to slightly over 2 hours.

Figures 8-11 present a summary list of the total duration of exceedances of the maximum allowable level of methane concentration and the downtimes registered by the methanometry sensors in the heading under analysis, taking into account their causes.

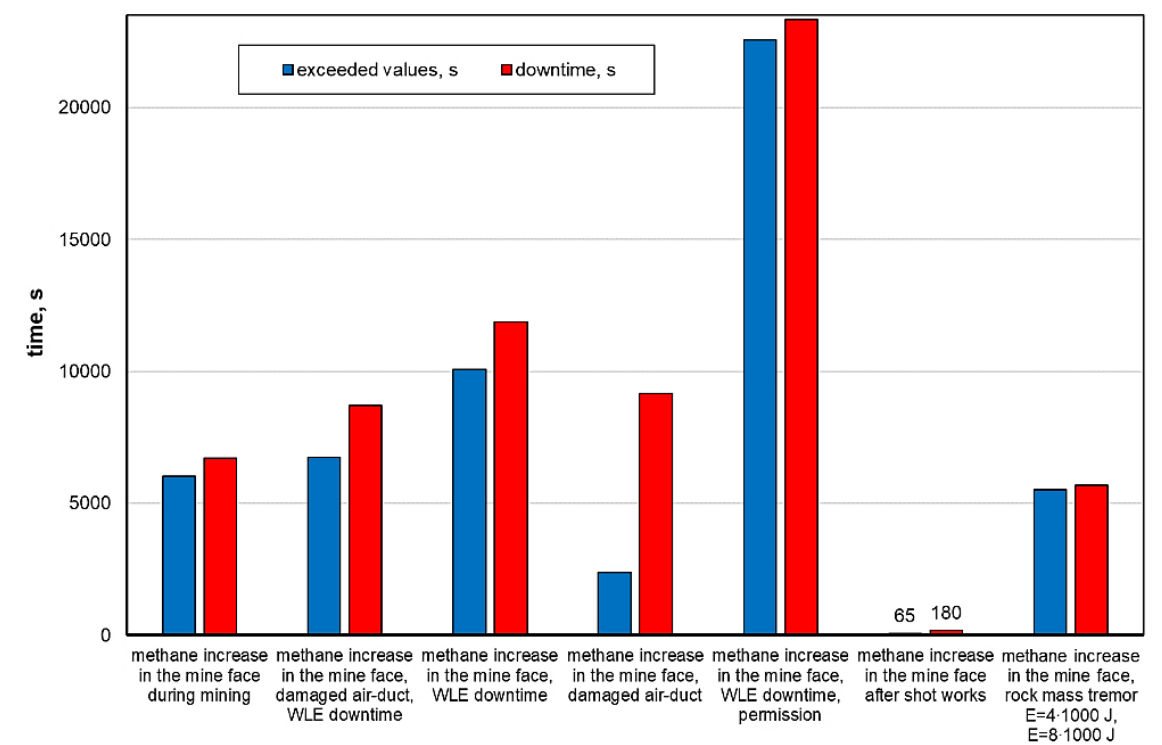

Fig. 8 The causes and exceedance times of the maximum allowable levels of methane concentration and the downtimes registered by the M-501 sensor

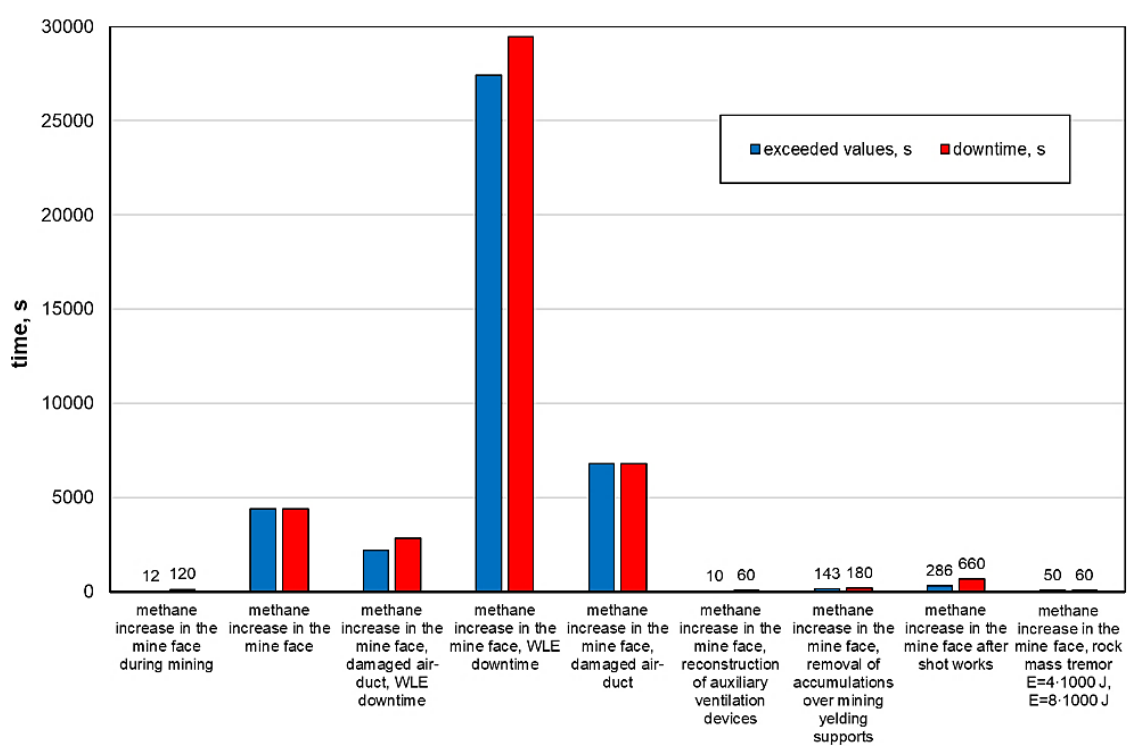

Fig. 9 The causes and exceedance times of the maximum allowable levels of methane concentration and the downtimes registered by the M-503 sensor 


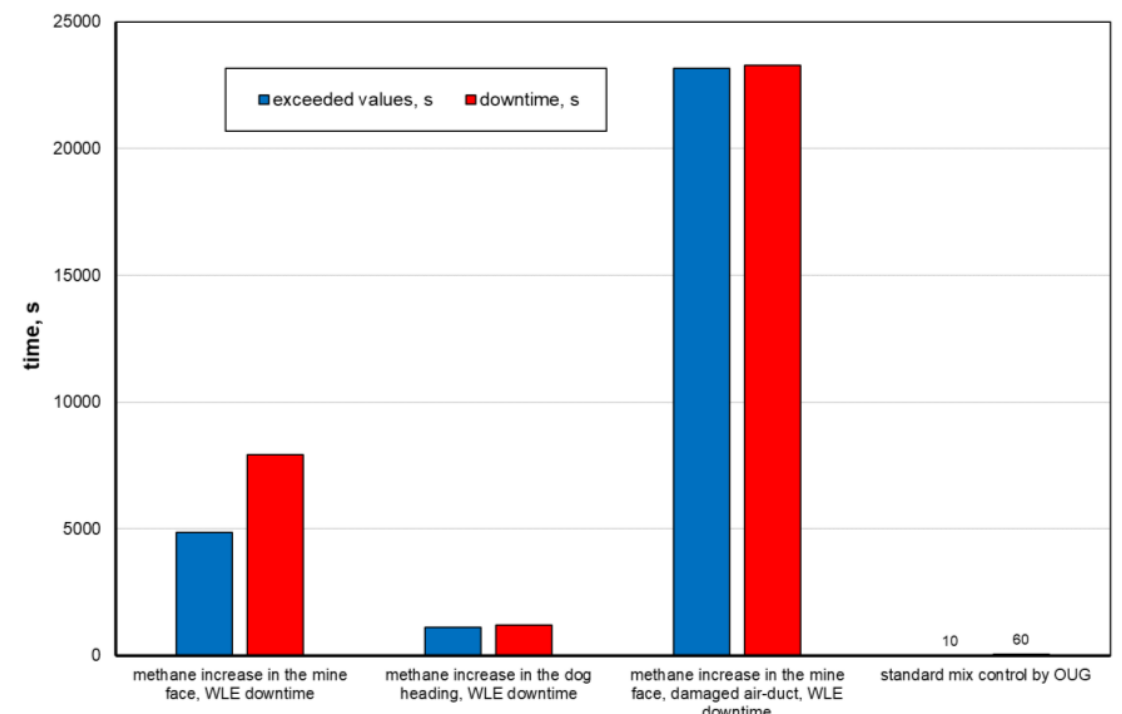

Fig. 10 The causes and exceedance times of the maximum allowable levels of methane concentration and the downtimes registered by the M-506 sensor

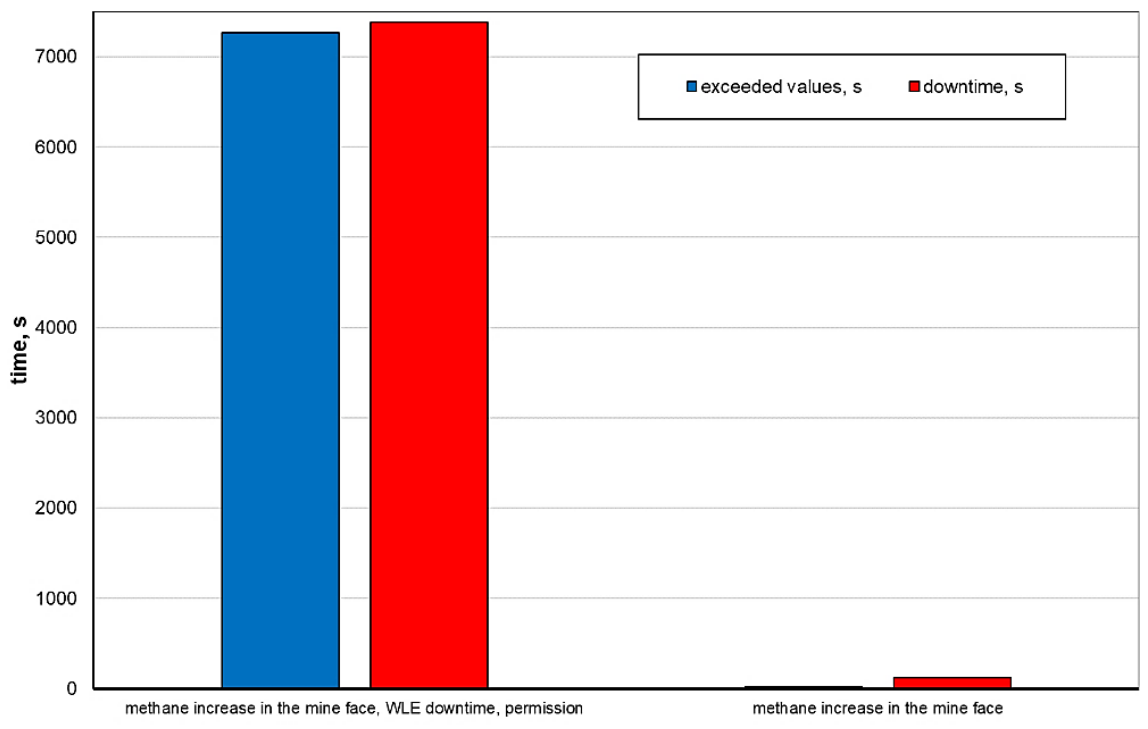

Fig. 11 The causes and exceedance times of the maximum allowable levels of methane concentration and the downtimes registered by the M-502 sensor

Based on the analysis of the presented causes behind the exceedances of the maximum allowable level of methane concentration and the ensuing downtimes, it may be concluded that they were most commonly caused by increased $\mathrm{CH}_{4}$ levels and the downtime of the air duct fan (WLE), as well as by increased methane content due to the damaged air duct and downtime of the WLE fan.

A summary list of the main causes behind the exceedances of the maximum allowable level of methane concentration for the analysed sensors over a period of 4 weeks, along with the summary duration of the exceedances and downtimes, is presented in Table 1, whereas Table 2 summarises the longest duration of exceedances of methane concentration and downtimes, along with the registered value of methane concentration causing each downtime. 
Table $1 \mathrm{~A}$ summary list of the main causes behind the exceedances of the maximum allowable level of methane concentration for the analysed sensors over a period of 4 weeks, along with the summary duration of the exceedances and downtimes

\begin{tabular}{|c|l|c|c|}
\hline \multirow{2}{*}{ Sensor } & \multicolumn{1}{|c|}{ Cause } & \multicolumn{2}{|c|}{ Time, s } \\
\cline { 3 - 4 } & \multicolumn{1}{|c|}{$\begin{array}{c}\text { exceeded } \\
\text { values }\end{array}$} & downtime \\
\hline 501 & $\begin{array}{l}\mathrm{CH}_{4} \text { increase in the mine face, WLE } \\
\text { downtime }\end{array}$ & 26712 & 27660 \\
\hline 502 & $\begin{array}{l}\mathrm{CH}_{4} \text { increase in the dog heading, WLE } \\
\text { downtime }\end{array}$ & 7265 & 7380 \\
\hline 503 & $\begin{array}{l}\mathrm{CH}_{4} \text { increase in the dog heading, WLE } \\
\text { downtime }\end{array}$ & 13424 & 15240 \\
\hline 506 & $\begin{array}{l}\mathrm{CH}_{4} \text { increase in the dog heading, WLE } \\
\text { downtime }\end{array}$ & 13840 & 13860 \\
\hline
\end{tabular}

Source: (Own study)

Table 2 A summary of the longest duration of exceedances of methane concentration and downtimes, along with the registered value of methane concentration causing each downtime

\begin{tabular}{|c|c|c|c|c|}
\hline \multirow[b]{2}{*}{ Sensor } & \multicolumn{2}{|c|}{ Time, $s$} & \multirow[b]{2}{*}{$\mathrm{CH}_{4}, \%$} & \multirow[b]{2}{*}{ Cause } \\
\hline & $\begin{array}{l}\text { exceeded } \\
\text { values }\end{array}$ & downtime & & \\
\hline 501 & 12237 & 12360 & 1.7 & $\begin{array}{l}\mathrm{CH}_{4} \text { increase in the mine face, } \\
\text { WLE downtime }\end{array}$ \\
\hline 502 & 6776 & 6780 & 2.1 & $\begin{array}{l}\mathrm{CH}_{4} \text { increase in the dog } \\
\text { heading, WLE downtime }\end{array}$ \\
\hline 503 & 12404 & 12420 & 1.8 & $\begin{array}{l}\mathrm{CH}_{4} \text { increase in the dog } \\
\text { heading, WLE downtime }\end{array}$ \\
\hline 506 & 11040 & 11040 & 1.0 & $\begin{array}{l}\mathrm{CH}_{4} \text { increase in the dog } \\
\text { heading, WLE downtime }\end{array}$ \\
\hline
\end{tabular}

Source: (Own study)

The total duration of the exceedances of the maximum allowable level of methane concentration caused by an increase in $\mathrm{CH}_{4}$ and the downtime of the WLE fan for all 4 sensors amounted to over 23 hours, and the duration of downtime - over 24 hours.

\section{CONCLUSION}

One of the key factors determining the continuity and effectiveness of the production process in underground hard coal mines is the natural hazards. The most dangerous of them is the methane hazard, which is a common problem in today's mining industry. Taking into account the mining and geological conditions in which the exploitation of coal seams occurs and the high concentration of mining operations, the methane hazard will be increasing, which makes it necessary to undertake actions in order to minimise the influence of methane on the exploitation process. This concerns longwall headings and roadways alike.

The analyses presented in the article, based on the measurement results of methane concentration in the roadway, clearly demonstrate that methane represents a huge problem for this process. The registered durations of the exceedance of the maximum allowable level of methane concentration and the 
ensuing downtimes are very high. This, in turn, will entail losses and incomplete utilisation of technical and resources by a given mine.

It is also interesting to look at the summary list of the causes of downtimes being registered. This demonstrates that the drivage of roadways is totally dependent on the reliability and efficiency (performance) of the duct line ventilation system. Therefore, the results obtained indicate that limiting the impact of the methane hazard on the process of mining production primarily rests with the ventilation service teams.

\section{ACKNOWLEDGEMENTS}

This article was prepared within the statutory research performed at Silesian University of Technology, Department of Production Engineering, Faculty of Organization and Management (13/030/BK-20/0059).

\section{REFERENCES}

Branny, M. and Filipek, W. (2008). Numerical simulation of ventilation of blind drifts with a force- exhaust overlap system in the condition of methan and dust hazards. Arch. Min. Sci., 53, pp. 221-234.

Brodny, J. and Tutak, M. (2016a). Analysis of methane emission into the atmosphere as a result of mining activity. Proceedings of 16th International Multidisciplinary Scientific GeoConference SGEM 2016, DOI: 10.5593/SGEM2016/HB43/S06.012.

Brodny, J. and Tutak, M. (2016b). Analysis of gases emitted into the atmosphere during an endogenous fire. Proceedings of 16 th International Multidisciplinary Scientific GeoConference SGEM 2016, pp. 75-82. DOI: 10.5593/SGEM2016/HB43/S06.011.

Brodny, J. and Tutak, M. (2018). Analysis of methane hazard conditions in mine headings. Tehnički vjesnik/Technical Gazette, 25 (1), pp. 271-276. DOI:10.17559/TV-20160322194812.

Brodny, J. and Tutak, M. (2019a). Forecasting the distribution of methane concentration levels in mine headings by means of model-based tests and in-situ measurements. Arch. Control Sci., 29, pp. 25-39.

Brodny, J. and Tutak, M. (2019b). Analysing the utilisation effectiveness of mining machines using independent data acquisition systems: a case study. Energies, 12 (13), art. no. 2505.

Dziurzyński, W., Pałka, T., Krach, A. and Wasielewski, S. (2015). Rozwój systemów symulacji procesu przewietrzania w rejonie ściany z uwzględnieniem czujników systemu gazometrii. Prace Instytutu Mechaniki Górotworu PAN, 17, pp. 3-19.

Krause, E. (2005). Profilaktyka w pokładach metanowych zagrożonych sejsmicznie. Prace Naukowe GIG - Górnictwo i Środowisko, 3, pp. 65-79.

Krause, E. (2015). Krótkoterminowe prognozy wydzielania się metanu podczas wybierania ścian. Archives of Mining Sciences, 60(2), pp. 629-642.

Krause, E., and Dziurzyński, W. (2015). Projektowanie eksploatacji pokładów węgla kamiennego w warunkach skojarzonego zagrożenia metanowo-pożarowego. Główny Instytut Górnictwa, Katowice.

Krause, E. (2019). Zagrożenie metanowe w kopalniach węgla kamiennego. Główny Instytut Górnictwa, Katowice.

Kurnia, J.C., Sasmito, A.P. and Mujumdar, A.S. (2014). Simulation of a novel intermittent ventilation system for underground mines. Tunnelling and Underground Space Technology, 42, pp. 206-215.

Ordinance of the Minister of Energy On detailed requirements for conducting underground mining operations of 23 November 2016 (Journal of Laws of 2016, No. 2017, item 1118, as amended). 
Szlązak, N. (2013). Metody odmetanowania pokładów węgla w górnictwie podziemnym. Górnictwo i Geologia, 8(4), pp. 75-88.

Szlązak, N. and Borowski, D. (2006). Badania wydzielania metanu do wyrobisk chodnikowych drążonych kombajnami w pokładach węgla. Górnictwo i Geoinżynieria, 30 , pp. 45-56.

Tutak, M. and Brodny, J. (2017). Analysis of Influence of Goaf Sealing from Tailgate On the Methane Concentration at the Outlet from the Longwall. IOP Conf. Series: Earth and Environmental Science 95042025 doi :10.1088/17551315/95/4/042025.

Tutak, M. and Brodny, J. (2018). Analysis of the impact of auxiliary ventilation equipment on the distribution and concentration of methane in the tailgate. Energies, 11, 3076.

Tutak, M. and Brodny, J. (2019). Predicting Methane Concentration in Longwall Regions Using Artificial Neural Networks. Int. J. Environ. Res. Public Health, 16, 1406

Tutak, M. (2020). The influence of the permeability of the fractures zone around the heading on the concentration and distribution of methane. Sustainability,12(1), art. no. 16 . 


\begin{abstract}
.
Methane is one of the most dangerous gases occurring in mining production. Being inseparably connected with the rock mass, it presents a serious risk to occupational safety and reduces the effectiveness of mining production. A particularly high methane hazard occurs directly during exploitation in longwall headings and the drivage of roadways. Exceeding the maximum allowable level of its concentration in these headings makes it necessary to disconnect all machines until this concentration level is reduced. This leads to unscheduled downtimes of such machines, thus increasing the costs of their operation and decreasing their effectiveness. The paper demonstrates the results from the analysis of machine downtimes in the drivage of roadways, caused by excessive methane concentration levels. The analyses were based on the indications from the system for automatic monitoring of the ventilation parameters in this heading. The results obtained clearly demonstrated that exceeded values of methane concentration caused a series of unexpected downtimes in the drivage process. As a result, the process was disturbed and its effectiveness reduced. The presented analyses are one of the first to address the issue of how methane emissions affect machine downtimes. However, this phenomenon represents a major problem that needs to be addressed comprehensively in order to minimise the losses arising out of the necessary disruptions to the exploitation process.
\end{abstract}

Keywords: methane hazard, dog headings, mining operations, methaneometry, process efficiency 